\title{
A Study on the Second Language Acquisition for Chinese Simple Directional Complement ${ }^{*}$
}

\author{
LI Yan \\ North China University of Technology, Beijing, China \\ Beijing Language and Culture University, Beijing, China
}

\begin{abstract}
Complement is a typical feature of Chinese grammar, and it seldom appears in other languages. Because of its complexity, it is very difficult for Chinese learners all over the world. The paper takes seven groups of simple directional complement (SDC), "V-Shang", "V-Xia", "V-Jin", "V-Chu”, "V-Kai", "V-Qi”, and "V-Hui”, as research goals. The investigation on second language acquisition (SLA) is carried out in terms of different native languages. The conclusion can be drawn that native language has a close relationship with SLA, because of their difference in Semantic Incorporation. In addition, the category of SDC is also an important factor influencing SLA.
\end{abstract}

Keywords: simple directional complement, second language acquisition, Semantic Incorporation

\section{Introduction}

In this paper, as is known from statistical analysis, there is an evident correlation between native language and SLA. The Chinese group is adopted as control group, and the difference in grasping Chinese SDC between foreign group and control group was used to evaluate their SLA. The differences are all significant. The grasping degree of SLA on SDC is as follows: Japanese group > Korean group > English group. Via comparative analysis, the difference of Semantic Incorporation also causes difficulty in learning SDC. There is an evident correlation between SLA and SDC category. In a word, two factors, native language and SDC category, may affect SLA.

Complement is a typical feature of Chinese grammar, and it seldom appears in other languages. According to ZHAO Shu-hua's research (ZHAO, 1995), directional complement (DC) accounts for $38 \%$ in all types of complements, as is revealed in Table 1.

In Chinese teaching as a foreign language, DC is also the emphasis and difficult point. The DC is extensively studied by researchers, and the research is mainly focused on two aspects: acquisition order and error analysis. For error analysis, the research is based on error classification, however, the influence of DC category was neglected.

The aim of this thesis is to discuss the effect of native language and DC category on SLA. To obtain definite and clear results, the SLA of simple directional complement (SDC) was investigated.

\footnotetext{
${ }^{*}$ Acknowledgements: This paper is supported by research funds of North China University of Technology for outstanding young scholars.

LI Yan, lecturer, Ph.D., North China University of Technology, Beijing Language and Culture University.
} 
Table 1

Frequency of Complements in Chinese Language

\begin{tabular}{lll}
\hline Types of complement & Times & Percent \\
\hline Directional & 1476 & $38 \%$ \\
Resultative & 1238 & $32 \%$ \\
Potential & 315 & $8 \%$ \\
Modal & 358 & $9 \%$ \\
Quantitative & 470 & $12 \%$ \\
Prepositional phrase & 25 & $1 \%$ \\
Total & 3882 & $100 \%$ \\
\hline
\end{tabular}

\section{Test on SDC}

\section{Test Participants}

Test participants are non-Chinese native speakers. They have been in China for more than one-year and have learned SDC grammar. Their Chinese level and characteristics are illustrated in Table 2 and Table 3.

Table 2

Distribution of Foreign Students' Gender, Native Languages, and Their Universities

\begin{tabular}{llllllll}
\hline & \multicolumn{2}{c}{ Gender } & \multicolumn{3}{c}{ Native language } & \multicolumn{2}{c}{ University } \\
\cline { 2 - 8 } & Male & Female & Korean & Japanese & English & Tsinghua & BLCU \\
\hline Number & 33 & 36 & 32 & 21 & 16 & 40 & 29 \\
Percent & $47.8 \%$ & $52.2 \%$ & $46.3 \%$ & $30 \%$ & $23.7 \%$ & $58 \%$ & $42 \%$ \\
\hline
\end{tabular}

Notes. BLCU refers to Beijing Language \& Culture University.

Table 3

Distribution of Chinese Level

\begin{tabular}{lllll}
\hline \multirow{2}{*}{ Native language } & \multicolumn{3}{c}{ Intermediate } & \multicolumn{2}{c}{ High } \\
\cline { 2 - 5 } Korean & Number & Percent & Number & Percent \\
Japanese & 27 & $85 \%$ & 5 & $15 \%$ \\
English & 18 & $85.4 \%$ & 3 & $14.6 \%$ \\
\hline
\end{tabular}

Notes. Intermediate Level refers to HSK 3-4 level or the equivalent.

High Level refers to HSK 5-6 level or the equivalent.

In contrast, 16 Chinese college students are chosen as control group, as is shown in Table 4. They major in Science and Technology (S \& T), Literature and History (L \& H), and Art respectively, and their education backgrounds are from undergraduate to Ph.D..

Table 4

Distribution of Control Group'S Characteristics

\begin{tabular}{lllllllll}
\hline & \multicolumn{3}{c}{ Gender } & \multicolumn{3}{c}{ Major } & \multicolumn{3}{c}{ Education background } \\
\cline { 2 - 9 } & Male & Female & S \& T & L \& H & Art & Undergraduates & Postgraduates & Ph.D. \\
\hline Number & 8 & 8 & 5 & 7 & 4 & 10 & 4 & 2 \\
Percent & $50 \%$ & $50 \%$ & $31.25 \%$ & $43.75 \%$ & $25 \%$ & $62.5 \%$ & $25 \%$ & $12.5 \%$ \\
\hline
\end{tabular}

Notes. All the participants are university students aged from 20 to 28 , thus the influences of career and age are not considered in this paper. 


\section{Research Design}

The items of test 1 were selected from HSK dynamic composition corpus of BLCU and foreign students' daily compositions (see Appendix). They can be used to judge whether the participants' language sense coordinates with SDC Grammar. The judgement level, from positive to negative, is labeled as 1, 2, 3, and 4, as is shown in Figure 1. Test 2 is to accomplish sentences according to given verbs by using SDC. Therefore the effect of SLA can be directly revealed (see Appendix).

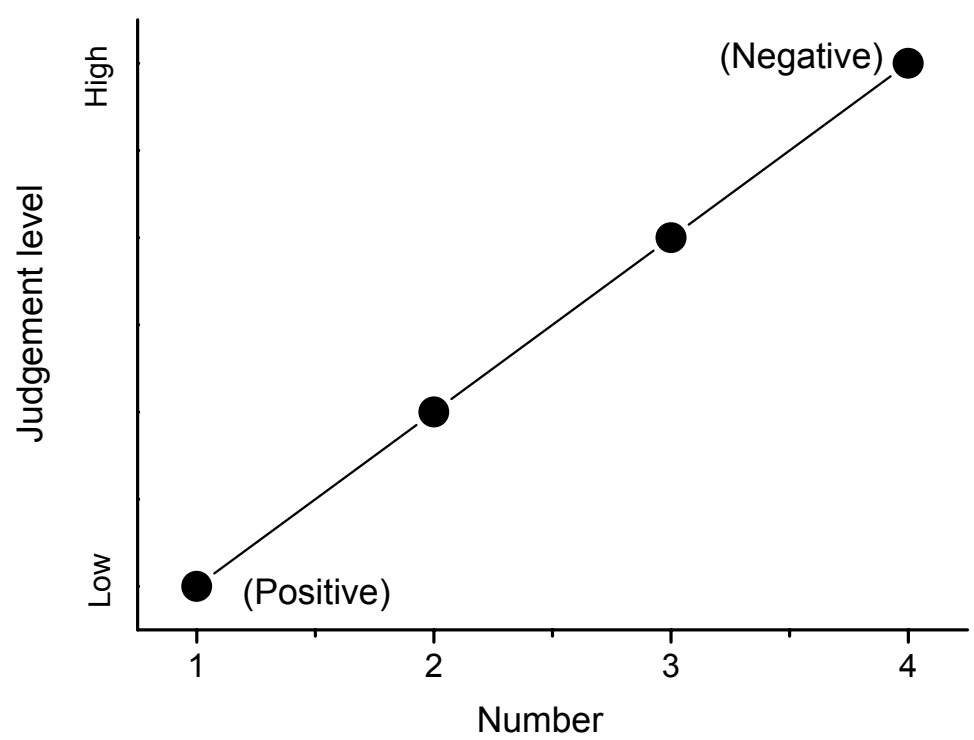

Figure 1. The relationship between judgement level and number label.

\section{Results and Discussion}

\section{Native Language and SLA}

Result of test 1 . The judgement level of each item in the four groups was analyzed respectively. The results are displayed in Table 5.

Table 5

Cross Table of Group and Judgement Level

\begin{tabular}{lllll}
\hline \multirow{2}{*}{ Group } & \multicolumn{4}{c}{ Judgement level } \\
\cline { 2 - 5 } & 1.00 & 2.00 & 3.00 & 4.00 \\
\hline Korean & $25.9 \%$ & $22.3 \%$ & $21.1 \%$ & $30.7 \%$ \\
Japanese & $16.8 \%$ & $29 \%$ & $31.1 \%$ & $23.1 \%$ \\
English & $30.1 \%$ & $24.7 \%$ & $21.4 \%$ & $23.8 \%$ \\
Chinese & $7.4 \%$ & $14.9 \%$ & $11.9 \%$ & $65.8 \%$ \\
\hline
\end{tabular}

The items in test 1 are extracted from inter-language, and they do not coordinate with Chinese SDC. As a whole, Chinese group, as the control group, has the highest judgement level. The Korean participants who chose 4 account for $30.7 \%$, thus, in terms of correct percentage, Korean group is the highest among foreign groups. The Japanese participants who chose 1 account for $16.8 \%$, thus, in terms of error percentage, Japanese group is the lowest among foreign groups. As to the total percentage of those who chose 2 and 3, Korean group is $43.4 \%$, 
Japanese group is $60.1 \%$, English group is $46.1 \%$, and the control group is $26.8 \%$. Compared with other foreign groups, Japanese students prefer uncertain answers.

In a word, there is of great difference in grasping SDC among non-Chinese native speakers.

Correlation analysis on test 1. In statistics (JIA, 2007), the influence of classified variable (native language) on numerical variable (judgement level), can be judged by contrasting each Population Mean. This method is called ANOVA (analysis of variance). P-value is the marker of the significant correlation. Therefore, the thesis can conclude that there is significant correlation between "native language" and "judgement level" (SLA), which can be found in Table 6 according to $\mathrm{P}$-value $(\mathrm{P}<0.001)$.

Table 6

ANOVA of Language and Judgement Level

\begin{tabular}{llllll}
\hline Difference source & Square sum & Freedom degree & Mean square & F & P-value \\
\hline Language & 194.715 & 3 & 64.905 & $53.720^{* * *}$ & .000 \\
\hline
\end{tabular}

On the premise of this conclusion, the influence of native language on SLA was investigated by General Liner Mode. ${ }^{1}$ The results are shown in Table 7.

Table 7

A Comparison of the Mean Score (MS) and Standard Deviation (SD)

\begin{tabular}{lll}
\hline Language & MS & SD \\
\hline Korean & 2.565 & .042 \\
Japanese & 2.605 & .052 \\
English & 2.390 & .060 \\
Chinese & 3.360 & .060 \\
\hline
\end{tabular}

The sequence of the MS is as follows: Chinese, Japanese, Korean, and English. To test significance in statistics, we need pairwise comparison between the four groups' Mean Difference. The result is shown in Table 8.

Table 8

Pariwise Comparison of Mean Difference

\begin{tabular}{lll}
\hline Groups & Mean difference (MD) & Sig. $^{\text {a }}$ \\
\hline Chinese-English & $.970^{*}$ & .000 \\
Chinese-Korean & $.795^{*}$ & .000 \\
Chinese-Japanese & $.755^{*}$ & .000 \\
Japanese-Korean & .040 & .553 \\
Japanese-English & $.216^{*}$ & .007 \\
Korean-English & $.176^{*}$ & .017 \\
\hline
\end{tabular}

Notes. ${ }^{*}$ The mean difference is significant at the .05 level; ${ }^{a}$ Adjustment for multiple comparisons: Least Significant Difference (equivalent to no adjustment).

First of all, Chinese, as a control group, was compared with Korean, Japanese, and English group respectively. According to statistics, their differences are all significant. The sequence of difference in MD is as

${ }^{1}$ GLM (General Liner Mode) include ANOVA and regression analysis. 
follows: Chinese-English group, Chinese-Korean group, and Chinese-Japanese group. We also made comparisons between foreign groups. Of all the three groups, only the difference between Japanese and Korean group is not significant. Therefore, English native language significantly affects the SLA of SDC, and the effects of Korean and Japanese native language are at the same level.

Comparative analysis. We compared English, Japanese, and Korean with Chinese respectively. The analysis is as follows.

Comparative analysis on Chinese-English. To study the impact of English native language on SLA, we investigated the judgement level of seven SDC categories. The results are revealed in Figure 2.

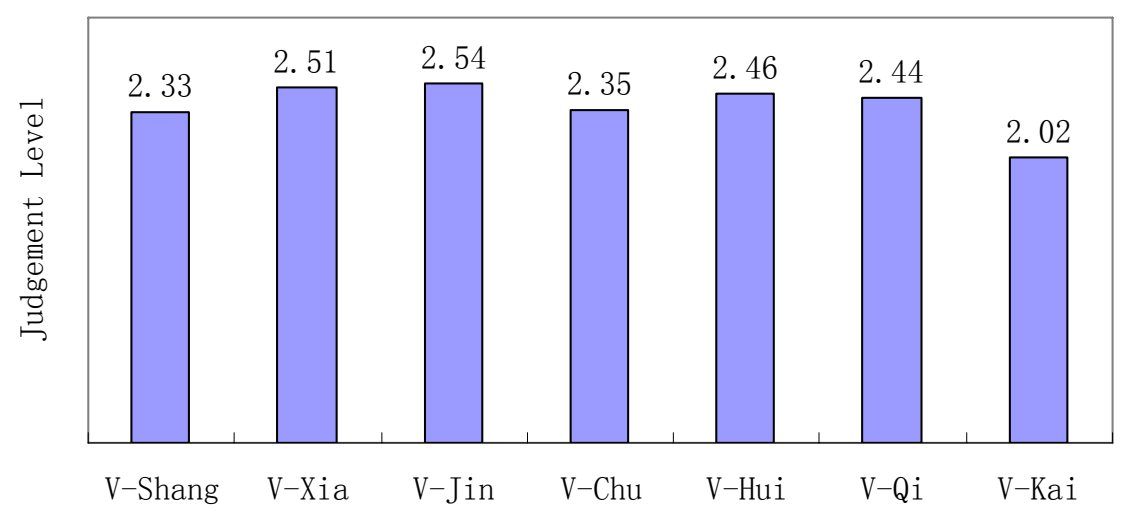

Figure 2. Judgement level in English group.

The English students made most mistakes in V-Kai. Besides this, they are apt to misuse V-Shang and V-Chu .

We take V-Shang and V-Kai as examples to make analysis. The examples of V-Shang are as follows:

(1) Tāmén guò de hěn xìngfú de shēnghuó. (inter-language)

Tāmén guò-shàng le hèn xìngfú de shēnghuó. (correct)

(2) Wǒ xīwàng wúlùn fādá guójiā háishi fāzhănzhōng guójiā, dōu néng chī lùsè shíp̌nn. (inter-language)

Wǒ xīwàng wúlùn fādá guójiā háishi fāzhănzhōng guójiā, dōu néng chī-shàng lüsè shípǐn. (correct)

Resultative Complement (RC) and SDC are mixed in inter-language of the first example. For inter-language of the second example, SDC is missed. The correct sentences translated into English are as follows.

(3) They have lived a happy life.

(4) I hope they can have green food, whether in developed countries or in developing ones.

In Chinese, V-Shang means "reaching the target". It is more difficult to grasp because of its abstractness. In addition, there is no corresponding word in English, thus V-Shang is often misused by English students.

An example of V-Kai is as follows:

(5) Rúguǒ yǒu rén zài wǒ de pángbiān kāishǐ xīyān, wǒ hěn nánshòu, hěn nán hūxī, lián yăn jing yě bù găn kāi. (inter-language)

Rúguǒ yǒu rén zài wǒ de páng biān kāi shǐ xī yān, wǒ hěn nánshòu, hěn nán hū xī, lián yăn jing yě bù găn zhēng kāi. (correct)

The underlined part in the correct sentence can be translated into English: Dare not open my eyes. 
In Chinese, when expressing "open eyes", we should use Verb + SDC. But in English one word "open" is OK. For English students, they spontaneously take English verb "Open" in contrast to Chinese "Kai". But the parallelism of English verb "Open" and Chinese Verb + SDC was neglected. So V-Kai becomes the difficulty of SLA.

In The Grammar Book (Celce-Murcia, Larsen-Freeman, \& Williams, 1999), it is pointed out that when a verb contains within its own meaning of a following preposition, it is often possible to omit the preposition; the verb then becomes transitive, and the prepositional complement becomes a direct object.

In English, there are lots of verbs containing direction and manner. However, there are no corresponding monosyllabic words in Chinese, and Adverbs, Preposition phrases, and other compositions must be added. On the other hand, some English verbs can directly correspond to Chinese Verbs. YAN Chen-song (1998) did some research on Lexicalization of Motion Events and verified the consistency between English and Chinese verbs.

The meaning of single form in one language can correspond to synthesis of several forms in another language, which is defined as Semantic Incorporation (YAN, 2004). The difference, in Semantic Incorporation of Lexicalization, is an important factor causing difficulty in English-Chinese or Chinese-English translation. The examples of SDC usage are shown in Table 9.

Table 9

Expression of SDC in Chinese and English

\begin{tabular}{llll}
\hline Chinese SDC & Example & English & Example \\
\hline \multirow{2}{*}{ V-Shang } & Tā pá-shàng le tīzi. & V-up & He climbed up the ladder. \\
& Qíng zàizhèqiān-shàng nǐdemíngzi. & V & Sign your name here, please. \\
V-Xia & Tā gǔn-xià le lóu. & V-down & roll down the stairs. \\
\multirow{2}{*}{ V-Jin } & gōng-xià dírén de qiáotóubăo & V & to take the enemy's bridgehead \\
\multirow{2}{*}{ V-Hui } & Păo-jìn fángjiān & V-in & to run into the room \\
& ná-huí shū & V-back & to bring back the book \\
& tuì-huí suǒyǒu gōngkuăn & V & to return all public funds \\
\hline
\end{tabular}

It may cause complexity when Chinese SDC is translated into English. Some SDC can correspond to English V + Prep/Adv, such as "pá-shàng tīzi" and "gǔn-xià lóu". Some SDC can be translated into single English verb, for example, "qiān-shàng míng” corresponding to "sign”, "gōng-xià" corresponding to "take", and "tuì-huî" corresponding to "return".

Generally speaking, the difficulties in learning SDC lie in two aspects: semantic abstractness and semantic incorporation. V-Shang can express resultative semantic meaning, and it is difficult for Chinese learners to grasp because of its abstractness. There is not only some consistency, but also a lot of differences in Semantic Incorporation of Chinese and English. The difference lies in the different expression methods of English and Chinese: The synthetic method is usually applied in English, and the analysis method is commonly used in Chinese. English students are not adapted to using Prep. or Adv., when writing and speaking Chinese. Thus they often misuse Chinese SDC. For example:

\section{Nóngnóng de hēiyān piāo le_tiānkōng. [piāo-shàng]}

The Chinese "piāo" corresponds to English verb "float" that can be explained as "move without resistance in air, water or gas". The "float" contains the meaning "upward". Therefore, "shàng" in Chinese SDC "piāo-shàng" is often neglected. 
Comparative analysis on Chinese-Japanese. To study the impact of Japanese native language on SLA, we investigated the judgement level of seven SDC categories. The results are revealed in Figure 3.

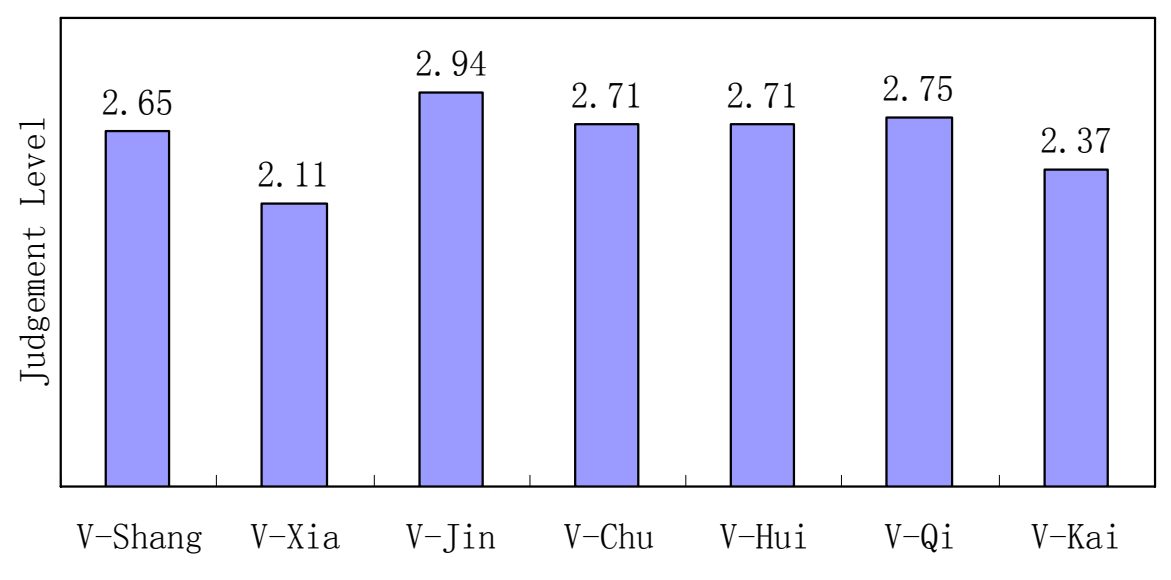

Figure 3. Judgement Level in Japanese group.

The Japanese students made most mistakes in V-Xia. We take V-Xia as an example to make analysis.

(6) Wó jiàndào tā jiù bùzhībùjué liú le yănlèi. (inter-language)

Wó jiàndào tā jiù bù zhī bù jué liú-xiàle yănlèi. (correct)

The underlined part in correct sentence can be translated into Japanese:

(7) 思わず涙が出ました。

出る $\rightarrow$ 出十ました $\Rightarrow$ 出ました

“出る” is equal to the prototype verb “liu”, and“ました” is the identifier of past tense and perfective aspect.

(8) Zhèzhǒng wèntí cháng shí jiān dōu zài wǒ mén de xīn zhōng liú xià. (inter-language)

Zhè zhǒng wèn tí cháng shi jiān liú zài wŏ mén xīn zhōng. (correct)

The underlined part in correct sentence can be translated into Japanese:

(9) 我々の心の奥に残っています。

残る 残っ十ています $\Rightarrow$ 残っています

“残つ” is equal to “liu (留)” in Chinese, “ています” is continuous. When V-Xia (Liu-Xia) in Chinese is translated into Japanese, auxiliary of Tense and Aspect should be attached to the Verb, the “ました” is the tense of past perfect and “ています” is aspect of continuous.

Japanese is agglutinative language, and has definite category of Tense and Aspect. Tense is a grammatical category, and it can demonstrate action, function, or state based on a specified time (e.g., speaking time). In Japanese, Tense is very typical for verb, including past and non-past. For example, "liú-xià yănlèi" should be expressed by past tense "た". The Aspect is used to demonstrate the state of action. Such Aspects include several types, such as prepare, future, continuous, perfective, and existential. Among these, continuous, perfective, and existential are basic Aspects (GU, 2004).

Inceptive in Japanese indicates the beginning of actions, equal to "be about to" or "on the point of" in English. In Japanese, it can be expressed via the form “始める”, “出す”, or “〜てくる”.

For example: 雨が降りはじめた/xià-qǐ le yǔ 
Inceptive in Japanese is very similar to Chinese "V-qi". Although the semantic of "V-qi" is abstract, it has not become the obstacle for Japanese students.

Contrastive analysis on Chinese-Korean. To study the impact of Korean native language on SLA, we investigated the judgement level of seven SDC categories. The results are revealed in Figure 4.

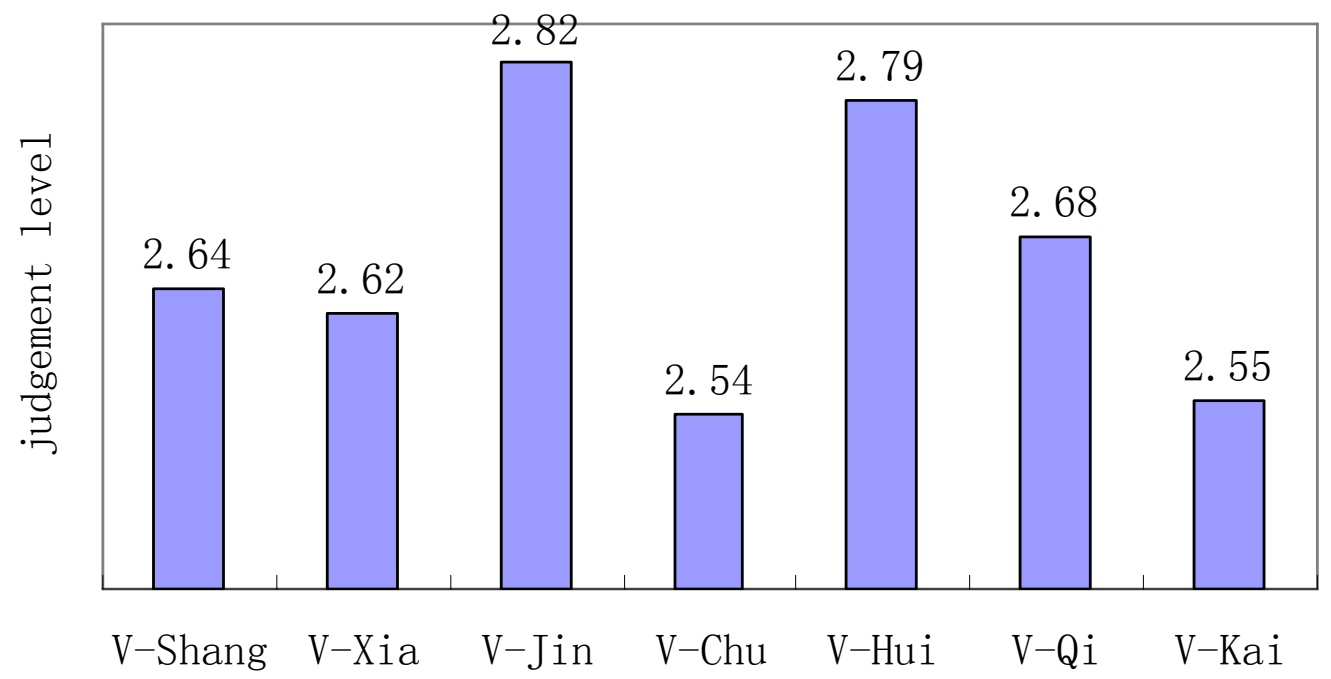

Figure 4. Judgement level in Korean group.

To analyze the reason of low judgement level, we investigated inter-language SDC according to error types, including missing, redundance, and misuse. The result is shown in Figure 5.

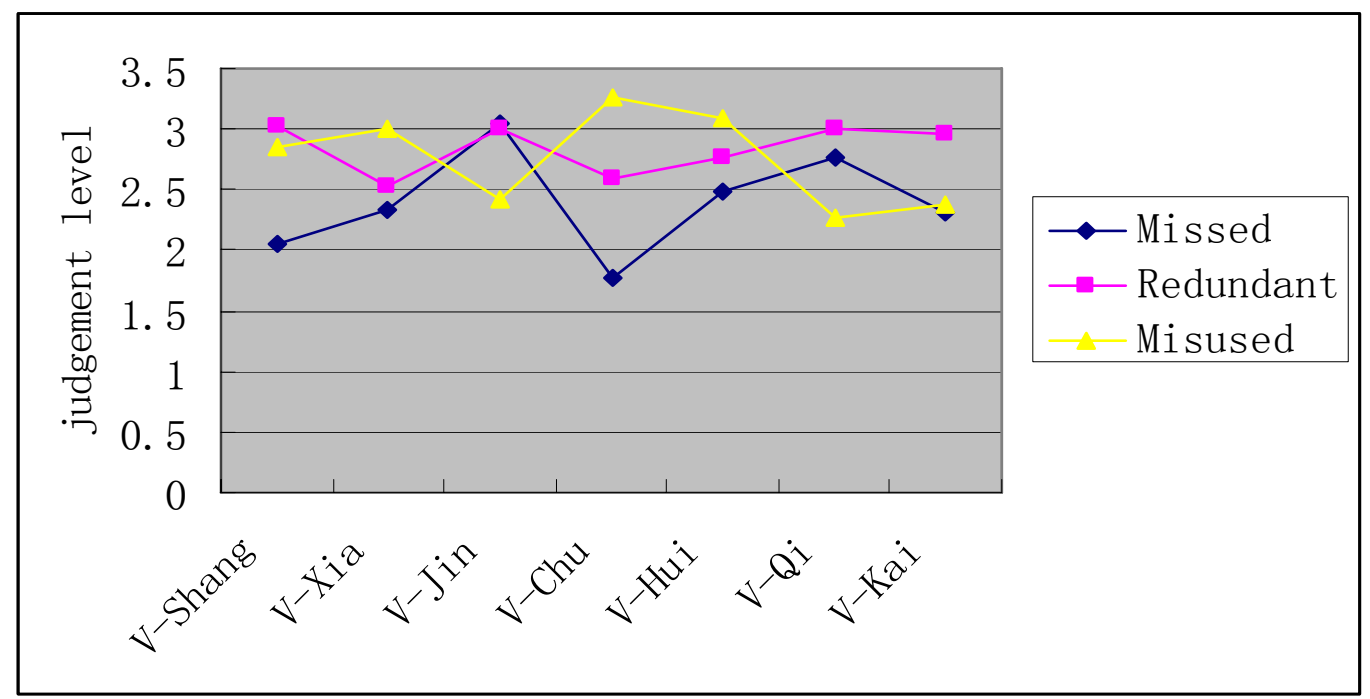

Figure 5. Statistics on category of Korean group.

As a whole, the judgement level for missing type is lower than the other two types, especially V-Chu and $\mathrm{V}$-Shang. The example of V-Chu is as follows:

(10) Wénzhāng de zuì hòu, zuòzhě xiě tā zìǰ de kànfă. (Inter-language)

Wénzhāng de zuìhòu, zuòzhě xiě-chū tā zij̀̆ de kànfă. (correct) 
The underlined part in correct sentence can be translated into Korean:

(11) 본인의 관점을 표연했다.

“표연 했다" in Korean is the Past Tense of verb "xie", without SDC. But in some cases, when Chinese SDC is translated into Korean, auxiliary verb is needed.

(12) 먼지를 닦아 버리다. (wipe off the dust)

"버리다" is widely used as telicity in Korean. It is an auxiliary verb with higher grammaticalization. In Korean, auxiliary is an Aspect category about action, attached to the verb, and is used to indicate telicity or continuous. For example, “-버리다" and "-내다” mean telicity, "-지다” means change (CUI \& MENG, 2007). Chinese SDC can be substituted by single verb or "verb + auxiliary" in Korean. The semantic of auxiliary in Korean corresponds to Chinese SDC or RC, causing the Korean students incapable of grasping Chinese SDC.

Chinese directional meaning can be expressed by SDC. In English, it can be expressed by satellite of prep. or Adv. In Korean and Japanese, the verbs contain the directional meaning, e.g., the verb “出る” in Japanese means downward.

Frame event can be expressed by satellite or core components. Thus, Talmy (2000a, 2000b) divided the world languages into two types. One is satellite-framed language whose frame event was expressed by satellite, e.g., English Russian and Atsugewi. The other is core-framed language whose frame event was expressed by core, e.g., Spanish, French, and Japanese.

In addition, the Semantic Incorporation is different in the same frame event, such as Chinese and English, which becomes the obstacle for foreign students to learn Chinese SDC.

\section{The SDC Category and SLA}

The judgement level of test 1 on seven SDC ("V-Chu", "V-Hui", "V-Jin", "V-Kai", "V-Qi", "V-Shang", and "V-Xia") were calculated, as is demonstrated in Table 10.

Table 10

The Judgement level of Foreign Students on Different SDC

\begin{tabular}{lllll}
\hline \multirow{2}{*}{ Category } & \multicolumn{3}{c}{ Judgement level } \\
\cline { 2 - 5 } & 1.00 & 2.00 & 3.00 & 4.00 \\
\hline V-Shang & $24.3 \%$ & $18.0 \%$ & $22.0 \%$ & $35.7 \%$ \\
V-Xia & $24.3 \%$ & $27.1 \%$ & $18.8 \%$ & $29.8 \%$ \\
V-Jin & $15.7 \%$ & $22.4 \%$ & $23.5 \%$ & $38.4 \%$ \\
V-Chu & $23.5 \%$ & $18.8 \%$ & $21.6 \%$ & $36.1 \%$ \\
V-Hui & $16.9 \%$ & $22.7 \%$ & $20.0 \%$ & $40.4 \%$ \\
V-Qi & $16.5 \%$ & $27.5 \%$ & $23.9 \%$ & $32.2 \%$ \\
V-Kai & $25.5 \%$ & $24.7 \%$ & $23.5 \%$ & $26.3 \%$ \\
\hline
\end{tabular}

For V-Hui and V-Jin, $40.4 \%$ and $38.4 \%$ of the foreign students are among the highest judgement level, moreover, only $16.9 \%$ and $15.7 \%$ of them are among the lowest judgement level. Thus V-Hui and V-Jin are easier to be grasped by foreigners.

For V-Kai, 26.3\% of the foreign students are among the highest judgement level, moreover, $25.5 \%$ of them are among the lowest judgement level highest. Thus, V-Kai is grasped worst by foreigners.

The SLA of V-Chu and V-Qi is better than that of V-Shang and V-Xia, as is displayed in Table 11. 
Table 11

Mean Score and Standard Deviation on SDC Category

\begin{tabular}{lll}
\hline Category & MS & SD \\
\hline V-Chu & 2.702 & .072 \\
V-Hui & 3.839 & .072 \\
V-Jin & 2.847 & .072 \\
V-Kai & 2.506 & .072 \\
V-Qi & 2.718 & .072 \\
V-Shang & 2.690 & .072 \\
V-Xia & 2.541 & .072 \\
\hline
\end{tabular}

The mean scores are different for each SDC category. Therefore, the SLA is related to Chinese SDC category.

The correlation of SLA with SDC category and native language was tested via ANOVA. The result is revealed in Table 12. Both native language and SDC category have an evident correlation with SLA.

Table 12

ANOVA of Language \& SDC Category on SLA

\begin{tabular}{llllll}
\hline Different source & SS & df & MS & F & P-value \\
\hline Language & 194.715 & 3 & 64.905 & $53.720^{* * *}$ & .000 \\
Category & 29.903 & 6 & 4.984 & $4.186^{* * *}$ & .000 \\
Language \& category & 33.647 & 18 & 1.869 & 1.570 & .060 \\
\hline
\end{tabular}

\section{Conclusion}

In this paper, we tested the influence of SDC on SLA, and made correlative analysis. As is known from statistical analysis, there is an evident correlation between native language and SLA. The Chinese group is adopted as control group, and the difference in grasping Chinese SDC between foreign group and control group was used to evaluate their SLA. The differences are all significant. The grasping degree of SLA on SDC is as follows: Japanese group > Korean group > English group. Via comparative analysis, the difference of Semantic Incorporation also causes difficulty in learning SDC. There is an evident correlation between SLA and SDC category. In a word, two factors, native language and SDC category, may affect SLA.

\section{References}

Celce-Murcia, M., Larsen-Freeman, D., \& Williams, H. (1999). The grammar book: An ESL/EFL teacher's course (2nd ed.). Boston: Heinle \& Heinle.

CUI, J., MENG, Y. Z. (2007). Comparative analysis of Chinese and Korean (p. 84). Beijing: Beijing Language and Culture University Press.

GU, M. Y. (2004). Standard Japanese grammar. Beijing: Higher Education Press.

JIA, J. P. (2007). Statistics. Beijing: China Renmin University Press.

Talmy, L. (2000a). Toward a cognitive semantics, Volume I: Concept structuring system. Cambridge: CUP.

Talmy, L. (2000b). Toward a cognitive semantics, Volume II: Typology and process in concept structuring. Cambridge: CUP.

YAN, C. S. (1998). A comparison of lexicalization of motion event between English and Chinese. Journal of Pla University of Foreign Languages, 6, 8-12.

YAN, C. S. (2004). Semantic incorporation: A comparison of verbal meanings between English and Chinese. Journal of Pla University of Foreign Languages, 12, 40-42.

ZHAO, S. H. (1995). Statistics and research on the modern Chinese sentences pattern. Language Teaching and Language Studies, 2, $11-26$. 
Appendix

测试一

姓名: 性别: 年龄:

国籍: 第一语言: 学校:

汉语水平: (HSK证书级别或在中国学习汉语的时间)

根据句意, 判断下面句子划横线的部分是否符合汉语语法, 并用数字表示合法度。

1 表示非常符合语法, 2 表示可能符合语法, 3 表示可能不符合语法, 4 表示非常不符合语法

1. 文章的最后，作者写他自己的看法。（Q4）

2. 所以人们把狼回到保护区。（Q5）

3. 我的脑子里出生了很多问题。（Q4）

4. 晚上, 我和安娜回来了我们的学校。（Q5）

5. 我这时回忆以前的很多事。（Q6)

6. 他们五个过得很幸福的生活。（Q1）

7. 妈妈什么也没说就把垃圾捡起来藏了自己的口袋。（Q3）

8. 他们非常爱上家里的人，所以产生了 “安乐死” 的想法。（Q1）

9. 我见到他就不知不觉流了眼泪, 我以为哥哥把我忘了。（Q2）

10. 如果有人在我的旁边开始抽烟, 我很难受, 很难呼吸, 连眼睛也不敢开。（Q7）

$\begin{array}{llll}1 & 2 & 3 & 4 \\ 1 & 2 & 3 & 4 \\ 1 & 2 & 3 & 4 \\ 1 & 2 & 3 & 4 \\ 1 & 2 & 3 & 4 \\ 1 & 2 & 3 & 4 \\ 1 & 2 & 3 & 4 \\ 1 & 2 & 3 & 4 \\ 1 & 2 & 3 & 4\end{array}$

11. 我希望无论发达国家还是发展中国国家, 都能吃 绿色食品。（Q1）

12. 我真恨不得马上变成燕子, 飞回去故乡。（Q5）

13. 比较穷的家庭会很难买农作物。（Q6)

14. 吃这样的食品, 人类会生出畸形的孩子, 甚至有的家庭的男女不能生下孩子。（Q2）

15. 因为跟朋友谈话的时候, 如果不知道他们说的 任何东西的话，不能进他们的空间去。（Q3)

16. 所以, 这种问题长时间都在我们的心中留下。（Q2）

17. 过了几分种以后, 他从容不迫地推门进来了。(Q7)

18. 大城市里的一般的家庭开冰箱满是吃的东西。（Q8)

19. 弟弟经常惹起母亲生气。（Q6）

20. 我首先走进去了一家卖手表的商店。（Q3）

21. 这里的短消息表明出很多人都认为吸烟队身体有害。

(Q4) 
测试二

姓名: 性别: 年龄:

国籍: 第一语言: 学校:

汉语水平: (HSK证书级别或在中国学习汉语的时间)

$\Delta$ 根据方括号中动词或词组，使用趋向补语的恰当形式完成下面的句子。

1. 村子里 了浓浓的黑烟。(飘)

[Q6]

2. 他的妻子 眼睛看着礼物, 但是她的表情没有变化。（睁）

3. 因人的本性, 再 其中一定有爱占便宜的人, 难免产生 “三个和尚没水喝” 的现象。（加）

4. 虽然这个工作很辛苦, 但他们三个人却 了深厚的友谊。(结)

[Q2]

5. 自杀之前一定要把自己的想法写在纸上, 并 。(签名) [Q1]

6. 千万不要 武器, 也千万不要把失败的苦放在心里。(放) [Q2]

7. 故事的这个结果让我 另一件事。(想) [Q6]

8 . 浓浓的黑烟 了天空。(飘) [Q1]

9. 对于环境污染问题, 各个国家都应该 , 不应该总等着别的国家解决问题。 （负责任） [Q6]

10. 在日本, 女人一般结婚以后辞去自己的工作, 家庭当家庭妇女。(走) [Q3]

11. 我跟她见面的时候, 她总是批评我, 我的缺点。(指) [Q4]

12. 父母的兴趣爱好、思想观念、行为举止, 无一不是从幼年就开始在孩子心目中 深深的烙印。(打) [Q2]

13. 他们往往都 长辈们对他们的劝导。(“听”否定)

[Q3]

14. 城市的离婚率不断地在增加, 现代的都市人对爱情都 了。(看) [Q7]

15. 那天我 了派出所，对警察说“我的钱被偷了!”（跑） [Q3]

16. 由于名利与地位的差距, 她跟丈夫 了离婚。（提） [Q4]

17. 首先要把菜 水里泡几分钟。（放） [Q3]

18. 70 年代的时候, 她就从国外 一台彩电。(带) [ Q5 ]

19. 可能现在谁也 这个谜。 (“解”否定) (Q7)

20. 他讲课的时候, 很高兴的样子。（表现）

21. 他的书店倒闭了，剩下的书刊都 家里，塞到了各个角落。(搬) [ Q5]

22. 目前我们到哪儿去都 噪音。（“躲避”否定） 